\title{
Optimization of a Reverse-Phase High Performance Liquid Chromatography (RP-HPLC) Method for Simultaneous Separation of Aloe-Emodin, Rhein, Emodin, Chrysophanol and Physcion
}

\author{
Gizem Yıldırım Baştemur ${ }^{1,2, *}$, Reyhan Akpınar ${ }^{3}$, Sabriye Perçin Özkorucuklu ${ }^{4}$, Esengül Kır ${ }^{5}$ \\ 1* Süleyman Demirel University, Institute of Graduate Studies in Sciences, Programme of Chemistry, Isparta, Turkey, (ORCID: 0000-0002-4634-4525), \\ gizemyildirimbastemur@istanbul.edu.tr \\ 2 Istanbul University, Faculty of Science, Department of Molecular Biology and Genetics, İstanbul, Turkey, (ORCID: 0000-0002-4634-4525), \\ gizemyildirimbastemur@istanbul.edu.tr \\ 3 Istanbul University, Institute of Graduate Studies in Sciences, Programme of Molecular Biotechnology and Genetics, İstanbul, Turkey, (ORCID: 0000-0001-5910- \\ 4160),reyhanakpnr1@gmail.com \\ ${ }^{4}$ Istanbul University, Faculty of Science, Department of Molecular Biology and Genetics, İstanbul, Turkey, (ORCID: 0000-0001-9778-2034), sabriyeo@istanbul.edu.tr \\ 5 Süleyman Demirel University, Faculty of Art and Science, Department of Chemistry, Isparta, Turkey, (ORCID: 0000-0002-6641-3444), esengulkir@sdu.edu.tr
}

(First received 26 August 2021 and in final form 28 November 2021)

(DOI: $10.31590 /$ ejosat.987628)

ATIF/REFERENCE: Yıldırım Baştemur, G., Akpınar, R., Perçin Özkorucuklu, S. \& Kır, Esengül. (2021). Optimization of a ReversePhase High Performance Liquid Chromatography (RP-HPLC) Method for Simultaneous Separation of Aloe-Emodin, Rhein, Emodin, Chrysophanol and Physcion. European Journal of Science and Technology, (27), 972-984.

\begin{abstract}
In this study, a reverse-phase high performance liquid chromatography (RP-HPLC) method with high separation efficiency, high detection sensitivity and excellent selectivity was successfully developed for the simultaneous determination of the aloe-emodin, rhein, emodin, chrysophanol, and physcion compounds. These optimum method conditions were determined by studying various columns, mobile phases and compositions, flow rates and column temperatures. The successful separation was carried out with a Supelcosil LC18 column $(250 \times 4.6 \mathrm{~mm}, 5 \mu \mathrm{m})$ and a gradient program. The procedure was carried out at $20{ }^{\circ} \mathrm{C}$ with the flow rate of $1.0 \mathrm{~mL} / \mathrm{min}$. and the injection volume of $20 \mu \mathrm{L}$ utilizing an RP-HPLC method with DAD detector at $225 \mathrm{~nm}$. Deionized water containing $0.5 \%$ (v/v) orthophosphoric acid and methanol was used as the mobile phases A and B. This study showed an optimized analytical method can be effectively utilized to the qualitative determination of anthraquinone compounds.
\end{abstract}

Keywords: Reverse Phase High Performance Liquid Chromatography, Anthraquinon, Secondary Metabolites, Method Optimization.

\section{Aloe-Emodin, Rhein, Emodin, Chrysophanol ve Physcion'un Eş Zamanlı Ayrımı için Ters Fazlı Yüksek Performanslı Sıvı Kromatografisi (RP-HPLC) Yönteminin Optimizasyonu}

$\ddot{O} \mathbf{z}$

Bu çalışmada, aloe-emodin, rhein, emodin, chrysophanol ve physcion bileşiklerinin eş zamanlı tayini için yüksek ayırma verimliliğine, yüksek saptama hassasiyetine ve üstün seçiciliğe sahip bir ters fazlı yüksek performanslı sıvı kromatografi (RP-HPLC) yöntemi başarıyla geliştirilmiştir. Optimum yöntem koşulları, çeşitli kolonlar, mobil fazlar ve bileşimleri, akış hızları ve kolon sıcaklıkları çalışılarak belirlenmiştir. Ayırma, Supelcosil LC-18 kolonu ( 250 x $4.6 \mathrm{~mm}, 5 \mathrm{um})$ ile gradient programda gerçekleştirilmiştir. Prosedür $20{ }^{\circ} \mathrm{C}^{\prime} \mathrm{de}, 1,0 \mathrm{~mL} / \mathrm{dk}$ akış hızı ve $20 \mu \mathrm{L}$ enjeksiyon hacmi ile $225 \mathrm{~nm}$ 'de DAD dedektörlü bir RP-HPLC yöntemi kullanılarak gerçekleştirilmiştir. Mobil faz A ve B olarak \%0,5 (v/v) ortofosforik asit içeren deiyonize su ve metanol kullanılmıştır. Bu çalışma, antrakinon bileşiklerinin kalitatif tayini için optimize edilmiş bir analitik yöntemin etkin bir şekilde kullanılabileceğini göstermiştir.

Anahtar Kelimeler: Yüksek Performans Sıvı Kromatografi, Antrakinon, Sekonder Metabolitler, Metot Optimizasyonu.

* Corresponding Author: gizemyildirimbastemur@istanbul.edu.tr 


\section{Introduction}

The secondary metabolites are distributed in the plant family in various ways, and their biological functions are specific to the generating plants in which they are ascertained (Wolfender et al., 2015). The natural anthraquinones are the valuable part of the secondary metabolites naturally found in Polygonaceae, Leguminosae, Rubiaceae, Liliaceae and Rhamnaceae (Yao et al., 2004). The natural anthraquinones are interesting due to wideranging applications, and bioactive properties like anticancer (Koyama et al., 2002; Su et al., 2005; Chen et al., 2007), antiinflammatory, antifungal (Agarwal et al., 2000), antimicrobial (Yanwen et al., 2005), diuretic, cathartic, laxative, vasorelaxing, antioxidant (Yen et al., 2000; Iizuka et al., 2004) and phytoestrogen activities (Chien et al., 2015; Locatelli, 2011; Reynolds, 2004). For the typical example; aloe-emodin and chrysophanol were found to possess anti-micro bacterial activities (Smolarz et al., 2013). It has also been discovered that emodin, aloe-emodin and rhein naturally possess antitumor activities, antiinflammatory and antiviral effects (Li-Weber, 2013). The rhein exhibit many biological properties, especially immunosuppressive, antiinflammatory, antitumor, anticancer (You et al., 2013). Additionally, the physcion remains a potential candidate in the field of anticancer drug discovery against human cervical cancer (Wijesekara et al., 2014).

There are various analytical methods used for the qualitative or the quantitative analysis of the anthraquinones like the High Performance Liquid Chromatography (HPLC) (Zhang\&Shi, 2010; Koyama et al., 2007; Zhang et al., 2013; Tian et al., 2012; Mandrioli et al., 2011) the Ultra-Performance Liquid Chromatography (UPLC) (Wang\&Shi, 2014; Hu et al., 2014), the Capillary Cone Electrophoresis (CZE) (Tian et al., 2007; Wang et al., 2004), the Micellar Electrokinetic Chromatography (MEC) (Kuo\&Su, 2003; Shang\&Yuan, 2003; Sun\&Yeh, 2205), the Capillary ElectroChromatography (CEC) (Lü et al., 2007), the Thin Layer Chromatography (TLC) (Singh et al., 2005), the High-Speed Counter Current Chromatography (HSCCC) (Guo et al., 2011), the Cyclic Voltammetry (Wang et al., 2010) and the Supercritical Fluid Chromatography (Aichner\&Ganzera, 2015) but are not sensitive enough. There are also extremely sensitive and reliable methods utilized with the HPLC-MS (Xu et al., 2008) and the GC-MS (ElSohly et al., 2004; Zuo et al., 2008) available but these sophisticated devices are expensive, which limits their usability. Among all these methods, an HPLC with various detection systems offers high selectivity, sensitivity and separation efficiency with short analysis time.

The aim of this study was to develop a straightforward, rapid and highly sensitive method for the simultaneous separation of aloeemodin, rhein, emodin, chrysophanol and physcion using diode array detector RP-HPLC. An effective separation of the five compounds of the similar chemical structure in only fifteen minutes was achieved with the developed method which also facilities elucidation and quantification of the structure of natural anthraquinones in plants.

\section{Material and Method}

All solvents (methanol, orthophosphoric acid), diclofenac (internal standard), uracil (t0) and standard compounds (aloeemodin, rhein, emodin, chrysophanol and physcion) were obtained from Sigma-Aldrich. All chemicals used were HPLC grade and water was purified in a Milli-Q water purification system (Millipore, Bedford, MA, USA).

\subsection{Instruments and Conditions}

A Shimadzu HPLC system composed of a LC- 10AD VP pump, SIL-30AC autosampler, a CTO-10AS column oven, a DGU-20A degasser and a SPD-M20A diode array detector (DAD) was utilized for chromatographic studies. The Supelcosil LC-18, the Mediterranea Sea 18 and the Cogent Phenyl Hydride columns used had the dimensions of a $25 \mathrm{~cm} \times 4.6 \mathrm{~mm}, 5 \mu \mathrm{m}$, a $15 \mathrm{~cm} \times$ $4.6 \mathrm{~mm}, 5 \mu \mathrm{m}$ and a $25 \mathrm{~cm} \times 4.6 \mathrm{~mm}, 4 \mu \mathrm{m}$, respectively. The gradient program was utilized for the chromatographic separation. The deionized water containing $0.5 \%(\mathrm{v} / \mathrm{v})$ orthophosphoric acid was used as the mobile phase A; the methanol was used as the mobile phase B. The time-volume changes in the gradient program were as follows: $0-2 \mathrm{~min} ., 0-70 \% \mathrm{~B} ; 2-4 \mathrm{~min} ., 70-75 \%$ B; 4-6 min., 75-80\% B; 6-8 min., 80-85\% B; 8-10 min., 85-90\% B; 10-12 min., 90\% B; 12-14 min., 90-85\% B; 14-16 min., 85$80 \% \mathrm{~B}$; and $16-18 \mathrm{~min} ., 80-70 \% \mathrm{~B}$. The total injection time was 20 minutes with the injection volume of $20 \mu \mathrm{L}$. The optimum column temperature was at the $20{ }^{\circ} \mathrm{C}$, the flow rate was at a 1.0 $\mathrm{mL} / \mathrm{min}$ and the DAD detector was set at $225 \mathrm{~nm}$.

\subsection{Preparation of Stock Solution}

The stock solutions of $250 \mu \mathrm{g} / \mathrm{mL}$ were traditionally prepared by dissolving the standard compounds (aloe-emodin, emodin, rhein, chrysophanol and physcion) in the methanol and properly storing at $4{ }^{\circ} \mathrm{C}$. The dilutions were carefully made in methanol at the effective concentration determined for each compound from the stock solutions and required injections were made.

Internal standard was intentionally employed in the method optimization. This standard method adequately compensates the possible errors for pipetting and injection volumes, and also likely changes in the physical parameters during pretreatment or preparation steps. If the internal standard is determined appropriately, both the systematic and the random errors can be eliminated. However, the chemical and physical properties of the internal standard should be similar to those under the study. The diclofenac was intentionally chosen as the internal standard in our study. Even though the chemical structure of the diclofenac is not similar to the compounds studied in terms of the selectivity, peak acuity, resolution and analysis time, it was decided that the diclofenac would be suitable as an internal standard. The diclofenac solution (I.S) was dissolved in methanol to carefully prepare $20 \mu \mathrm{g} / \mathrm{mL}$ solution.

The uracil solution of $20 \mu \mathrm{g} / \mathrm{mL}$ prepared in methanol was chosen as the dead time $\left(\mathrm{t}_{0}\right)$ to determine the capacity factors. The average retention time of the uracil was precisely determined with three injections without holding in the HPLC column. The standards, diclofenac, uracil solutions and mobile phases were filtered by a $0.45 \mu \mathrm{m}$ pour size membrane filter.

\subsection{Chemicals}




\section{Results and Discussion}

\subsection{Method Optimization}

The most essential criteria for method development in chromatography systems can be listed as the analysis of the compounds in the shortest time possible, ensuring a good separation and obtaining symmetrical peaks. In providing these criteria; the actors like the chemical structure, the diameter and the length of the columns, the wavelength of compounds, the injection volume, the mobile phase composition, the flow rate and the column temperature have to be studied carefully. These criteria were taken into consideration in method optimization during the method development process to simultaneously determine the aloe-emodin, rhein, emodin, chrysophanol and physicon compounds.

The most properly used test for the optimization of RP chromatography is the resolution between peak pairs. Achieving a good resolution between all of the compounds under study is the main goal of chromatographic separation. On account of fundamental chromatographic parameters, the resolution, Rs., is affected by three independent variables:

$$
\mathrm{R}_{\mathrm{s}}=(1 / 4) \sqrt{ } \mathrm{N}[(\alpha-1) / \alpha]\left[\mathrm{k}_{2} /\left(\mathrm{k}_{2}-1\right)\right]
$$

In general, for the separation to take place; the capacity factor $(\mathrm{k})$ must be greater than 1 , the selectivity factor $(\alpha)$ greater than 1.15 , and the resolution (Rs.) values must be greater than 1.5. For all optimization parameters Rs. values were calculated for all peak pairs according to Eq. (1).

\section{Wavelength}

The wavelengths at which the compounds in this study have the highest absorbance were determined properly using a DAD detector. The spectral scan graphs obtained are given in the Figure 1. It is clearly seen from the Figure 1 that all the compounds studied had a maximum absorbance at $225 \mathrm{~nm}$. For the diclofenac (I.S) used as internal standard, the maximum absorbance wavelength of $205 \mathrm{~nm}$ was chosen (Figure 1b).
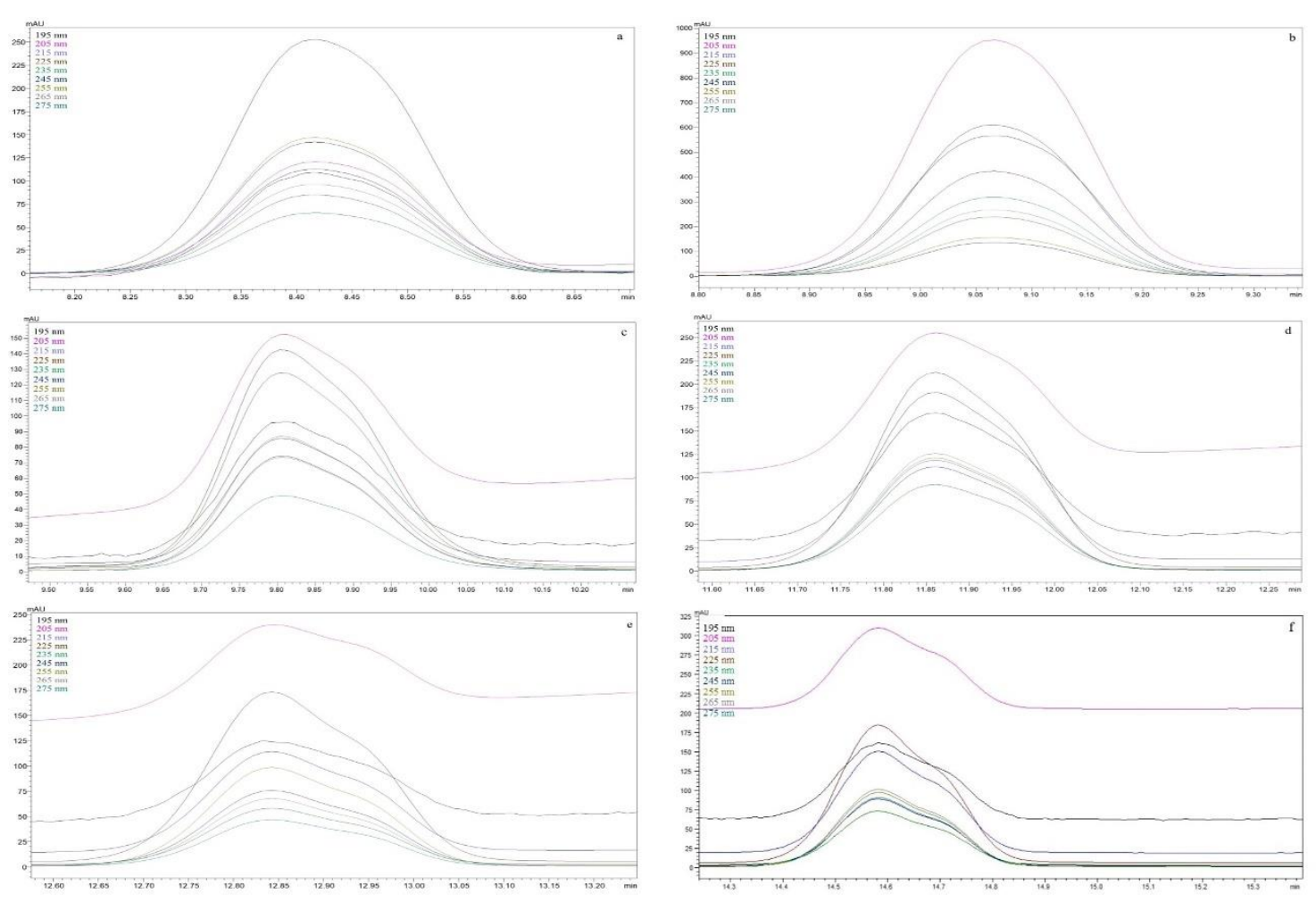

Figure 1. $\lambda \max$ values of the compounds obtained by using DAD detector (a-Aloe-emodin, b-I.S c-Rhein, d-Emodin, eChrysophanol, f-Physicon)

In the literature, the following wavelength results in the quantitative determination studies of aloe-emodin, rhein, emodin, chrysophanol and physicon were reported: Uzun and Demirezer (Uzun\&Demirezer, 2019) at $440 \mathrm{~nm}$ (DAD detector), Liu et al., (Liu et al., 1997) at 280 and $450 \mathrm{~nm}$ (DAD detector), Gautam et al. (Gautam et al., 2011), Farooq et al., (Farooq et al., 2013) and
Mehta (Mehta, 2012) at $254 \mathrm{~nm}$ (DAD and UV detector) with a HPLC.

\section{Injection volume}

Injection of all six compounds with five different injection volumes $(10 \mu \mathrm{L}, 20 \mu \mathrm{L}, 30 \mu \mathrm{L}, 40 \mu \mathrm{L}$ and $50 \mu \mathrm{L})$ were conducted for the determination of the optimum injection volume. The 
chromatograms in the Figure 2 were obtained which shows that the peak shapes do not change with the different injection volumes. Therefore, a $20 \mu \mathrm{L}$ injection volume was chosen as the optimum value to minimize material losses.

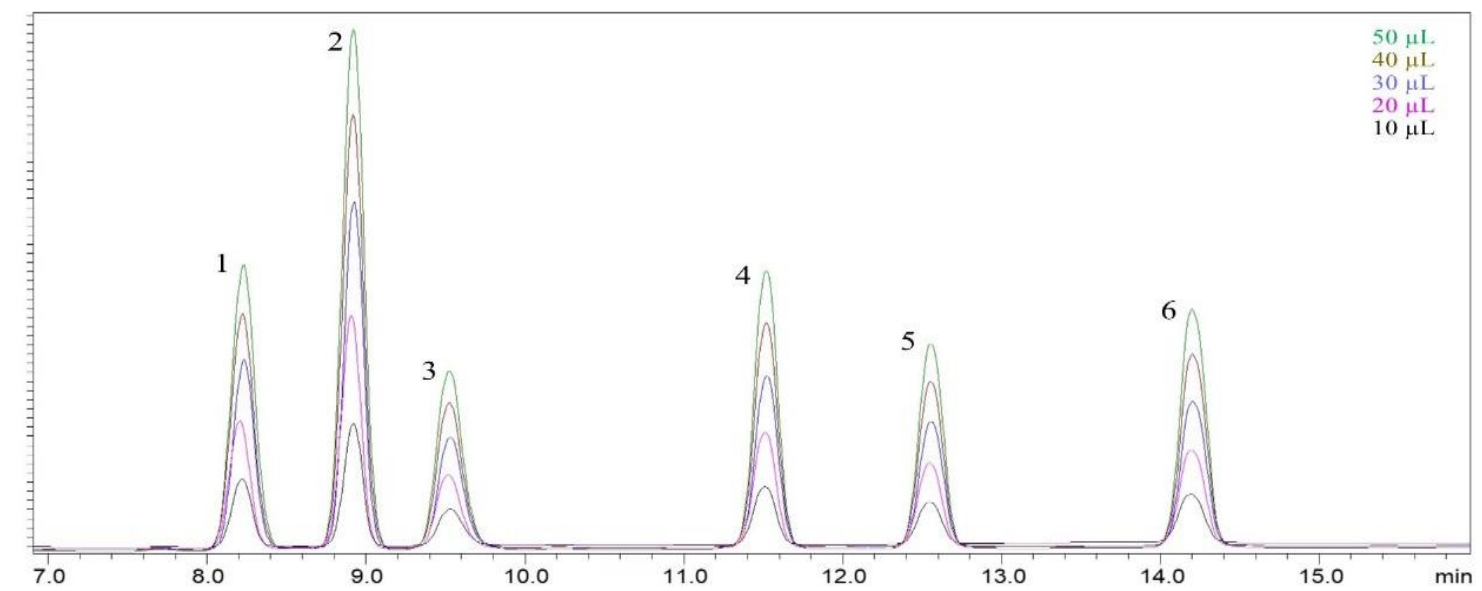

Figure 2. The standard mixture chromatograms obtained from different injection volumes of the compounds (1-Aloe-emodin, 2-I.S 3Rhein, 4-Emodin, 5-Chrysophanol, 6-Physicon)

\section{Column selection}

The column length and the column filler particle sizes are also important parameters for effective separation in the chromatography. Therefore, three different columns with different dimensions and particle sizes (Mediterranea Sea $18(150 \mathrm{~mm} \times$ 4.6mm, $5 \mu \mathrm{m})$, Cogent Phenyl Hydride $(250 \mathrm{~mm} \times 4.6 \mathrm{~mm}, 4 \mu)$ and Supelcosil LC-18 $(250 \mathrm{~mm} \times 4.6 \mathrm{~mm}, 5 \mu \mathrm{m}))$ were studied. While dimensions of the Cogent Phenyl Hydride and Supelcosil LC-18 columns are the same, the dimensions of the Mediterranea Sea 18 is different. In addition, the particle sizes of the the Cogent Phenyl Hydride and Supelcosil LC-18 columns were chosen differently from each other. The results obtained with three different columns are given in the Table 1. The resolution (Rs) values below 1.5 were obtained for I.S-Aloe-emodin and Physcion-Chrysophanol peak pairs in the Cogent Phenyl Hydride column and as clearly seen from the Figure $3 \mathrm{a}$, these peaks were not separated effectively. The Rs. values calculated in the Supelcosil LC-18 column were higher than those in the Mediterranea Sea 18 column. In addition, high peaks were obtained with the the Mediterranea Sea 18 column, but the shapes of these peaks are not very good (Figure 3b). As seen in Figure $3 \mathrm{c}$, the best separation and peak shapes were obtained with Supelcosil LC-18 column and thus, it was decided to conduct the study with this column.
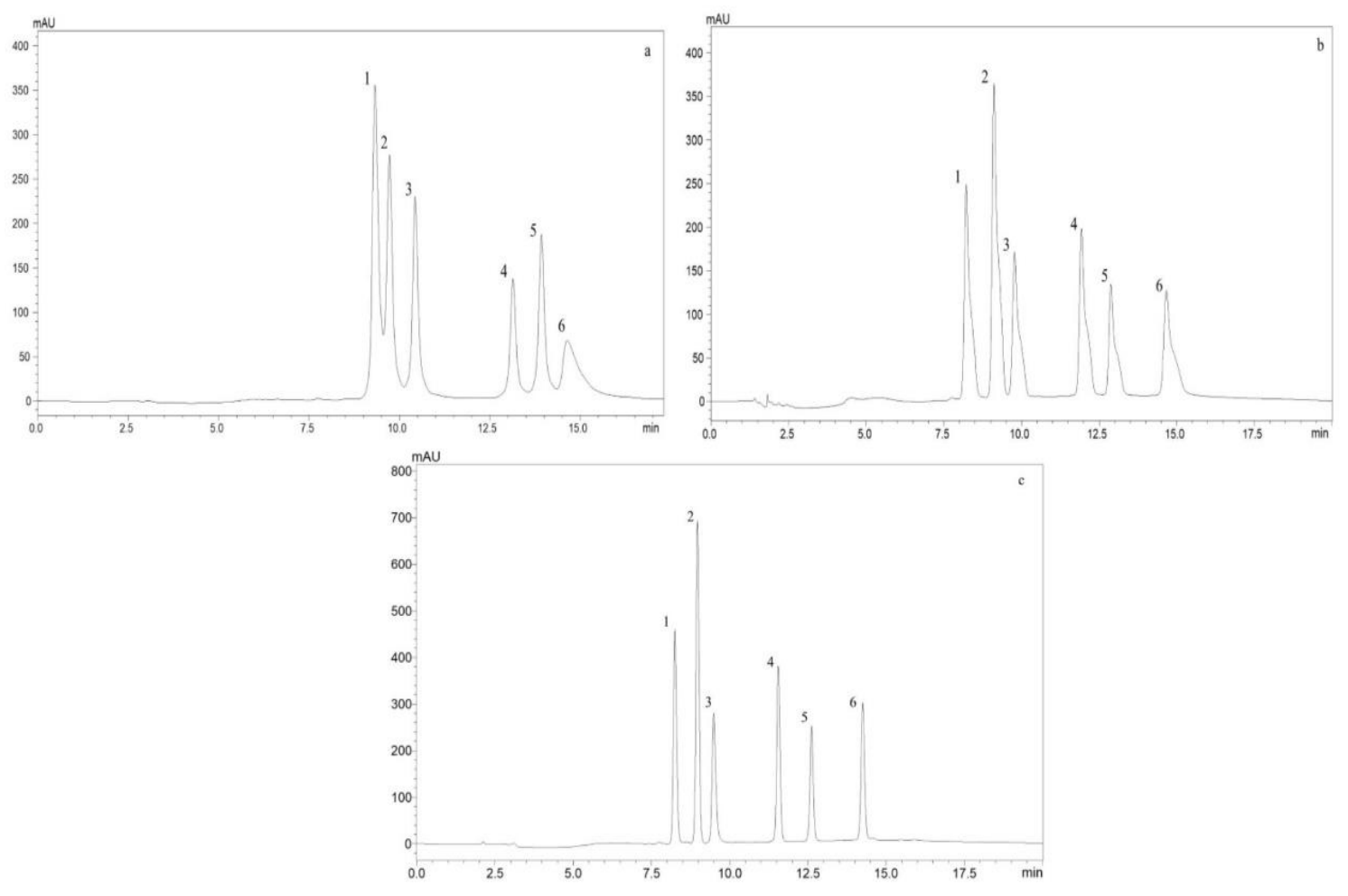
Figure 3. The standard mixture chromatograms of the compounds obtained (1-Aloe-emodin, 2-I.S 3-Rhein, 4-Emodin, 5Chrysophanol, 6-Physicon) in different columns a) Cogent Phenyl Hydride, b) Mediterranea Sea 18 c) Supelcosil LC-18

Table 1. Comparison of the values obtained for all the compounds in the different columns

\begin{tabular}{|c|c|c|c|c|c|c|c|}
\hline Column & Compounds & $\mathbf{k}_{2}$ & $\alpha$ & $k_{2} /\left(k_{2}+1\right)$ & $(\alpha-1) / \alpha$ & $(1 / 4) \sqrt{N}$ & $\mathbf{R}_{\mathbf{s}}$ \\
\hline \multirow{5}{*}{$\begin{array}{l}\text { Cogent Phenyl } \\
\text { Hydride }\end{array}$} & I.S/Aloe-emodin & 2.142 & 1.065 & 0.682 & 0.061 & 30.656 & 1.275 \\
\hline & Rhein/I.S & 2.371 & 1.107 & 0.703 & 0.097 & 35.221 & 2.402 \\
\hline & Emodin/ Rhein & 3.246 & 1.369 & 0.764 & 0.270 & 43.575 & 8.989 \\
\hline & Chrysophanol/Emodin & 3.501 & 1.079 & 0.778 & 0.073 & 45.326 & 2.574 \\
\hline & Physcion/Chrysophanol & 3.734 & 1.067 & 0.789 & 0.063 & 18.062 & 0.898 \\
\hline \multirow{5}{*}{$\begin{array}{l}\text { Mediterranea } \\
\text { Sea } 18\end{array}$} & I.S/Aloe-emodin & 2.633 & 1.221 & 0.725 & 0.181 & 30.214 & 3.965 \\
\hline & Rhein/I.S & 2.900 & 1.101 & 0.744 & 0.092 & 30.649 & 2.098 \\
\hline & Emodin/ Rhein & 3.761 & 1.297 & 0.790 & 0.229 & 38.024 & 6.879 \\
\hline & Chrysophanol/Emodin & 4.140 & 1.101 & 0.805 & 0.092 & 41.650 & 3.085 \\
\hline & Physcion/Chrysophanol & 4.854 & 1.172 & 0.829 & 0.147 & 34.529 & 4.208 \\
\hline \multirow{5}{*}{$\begin{array}{c}\text { Supelcosil LC- } \\
18\end{array}$} & I.S/Aloe-emodin & 1.916 & 1.137 & 0.657 & 0.120 & 46.727 & 3.684 \\
\hline & Rhein/I.S & 2.076 & 1.083 & 0.675 & 0.077 & 42.567 & 2.212 \\
\hline & Emodin/ Rhein & 2.743 & 1.321 & 0.733 & 0.243 & 55.438 & 9.875 \\
\hline & Chrysophanol/Emodin & 3.093 & 1.128 & 0.756 & 0.113 & 60.449 & 5.164 \\
\hline & Physcion/Chrysophanol & 3.621 & 1.171 & 0.784 & 0.146 & 64.903 & 7.429 \\
\hline
\end{tabular}

In a study by VanMen et al., (VanMen et al., 2012), a $25 \mathrm{~cm}$ long Optimapak C18 column was used where the retention times of approximately 29 and 31 minutes were determined for the emodin and the chrysophanol, respectively. Another study by Mehta (Mehta, 2012) with a $25 \mathrm{~cm}$ long C18 column reported the retention times of 10.75 for the rhein and 16.31 minutes for the emodin. Similar studies were carried out by Zou et al., (Zou et al., 2008) in a $15 \mathrm{~cm}$ long Phenyl-Hexyl column and Shi et al., (Shi et al., 2014) in a $25 \mathrm{~cm}$ long Diamonsil C18 column and the same retention times for aloe-emodin, rhein, emodin, chrysophanol and physcion were found with the results obtained in our study with $25 \mathrm{~cm}$ long Supelcosil C18 column.

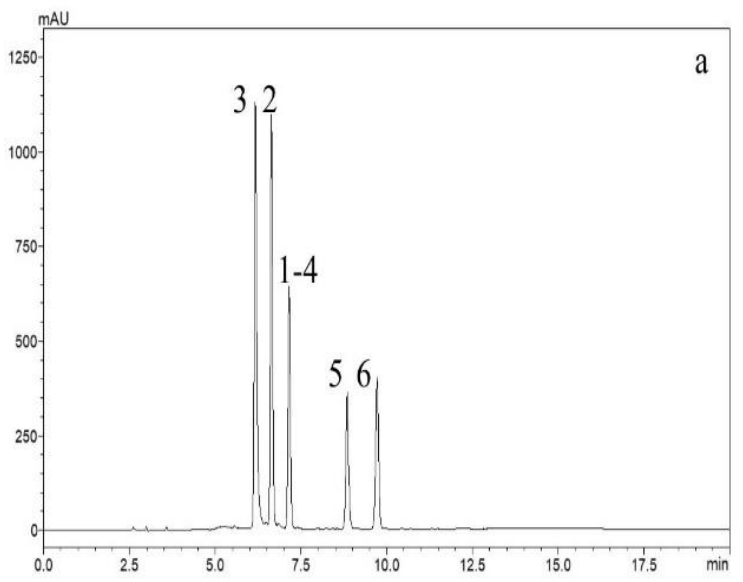

\section{Mobile phase}

The methanol and the acetonitrile were studied to determine the mobile phase $\mathrm{B}$ composition and the data obtained were compared. As seen in the Figure $4 \mathrm{a}$, the retention times of the compounds are shorter in the acetonitrile phase than in the methanol phase, but the separation could not be achieved since the aloe-emodin and the emodin compounds arrived at the same retention time. However, the separation of all compounds in the methanol was achieved (Figure $4 \mathrm{~b}$ ) and symmetrical peaks were obtained. As a result, the B mobile phase was determined to be methanol and the data obtained are given in Table 2.

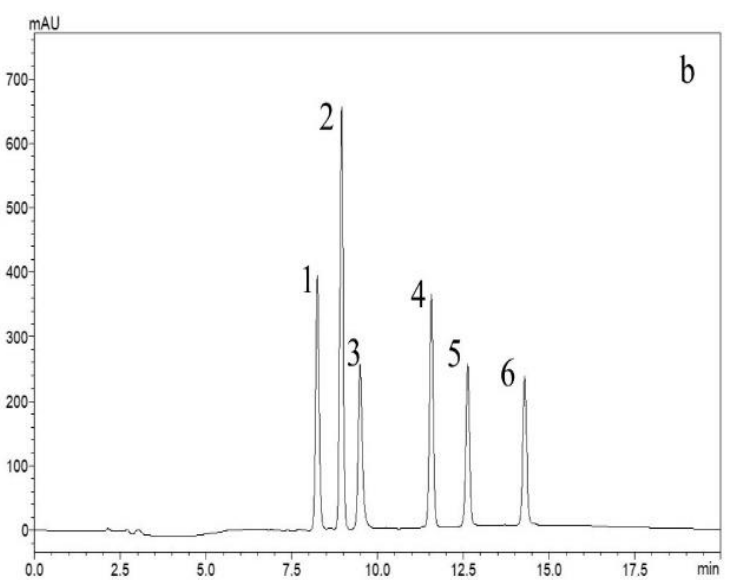

Figure 4. Standard mixture chromatograms of the different compounds (1-Aloe-emodin, 2-I.S 3-Rhein, 4-Emodin, 5-Chrysophanol, 6-Physicon) obtained in a) Acetonitrile b) Methanol 
Table 2. Values obtained for the methanol as the mobile phase B

\begin{tabular}{|c|c|c|c|c|c|c|c|}
\hline \multirow{3}{*}{$\begin{array}{c}\text { Mobile } \\
\text { Phase B }\end{array}$} & Compounds & $\mathbf{k}_{2}$ & $\boldsymbol{\alpha}$ & $\mathbf{k}_{\mathbf{2}} /\left(\mathbf{k}_{\mathbf{2}}+\mathbf{1}\right)$ & $\mathbf{( \alpha - 1 ) / \boldsymbol { \alpha }}$ & $\mathbf{( 1 / 4 )} \sqrt{\mathbf{N}}$ & $\mathbf{R}$ \\
\hline & I.S/Aloe-emodin & 1.901 & 1.134 & 0.655 & 0.118 & 46.152 & 3.567 \\
\cline { 2 - 8 } & Rhein/I.S & 2.076 & 1.092 & 0.675 & 0.084 & 41.954 & 2.379 \\
\cline { 2 - 8 } Methanol & Emodin/Rhein & 2.747 & 1.323 & 0.733 & 0.244 & 55.008 & 9.838 \\
\cline { 2 - 8 } & Chrysophanol/Emodin & 3.091 & 1.125 & 0.756 & 0.111 & 60.071 & 5.041 \\
\cline { 2 - 8 } & Physcion/Chrysophanol & 3.626 & 1.173 & 0.784 & 0.147 & 62.699 & 7.226 \\
\hline
\end{tabular}

In the gradient studies conducted in the literature, acetonitrilewater (Wang et al., 2013; Gao et al., 2009; Rafaelly et al., 2008) and the methanol-water (Uzun\&Demirezer, 2019; Gautam et al., 2011; Wang et al., 2016) mobile phases are used. In this study, both mobile phases were studied, but the separation of the compounds could not be achieved in the acetonitrile mobile phase. In the experiments, five different ratios of the orthophosphoric acid-deionized water mixture $(0.0 \%-0.01 \%-$ $0.1 \%-0.5 \%-1.0 \%$ ) were studied as the mobile phase A composition and the chromatograms obtained are given in the Figure 5.

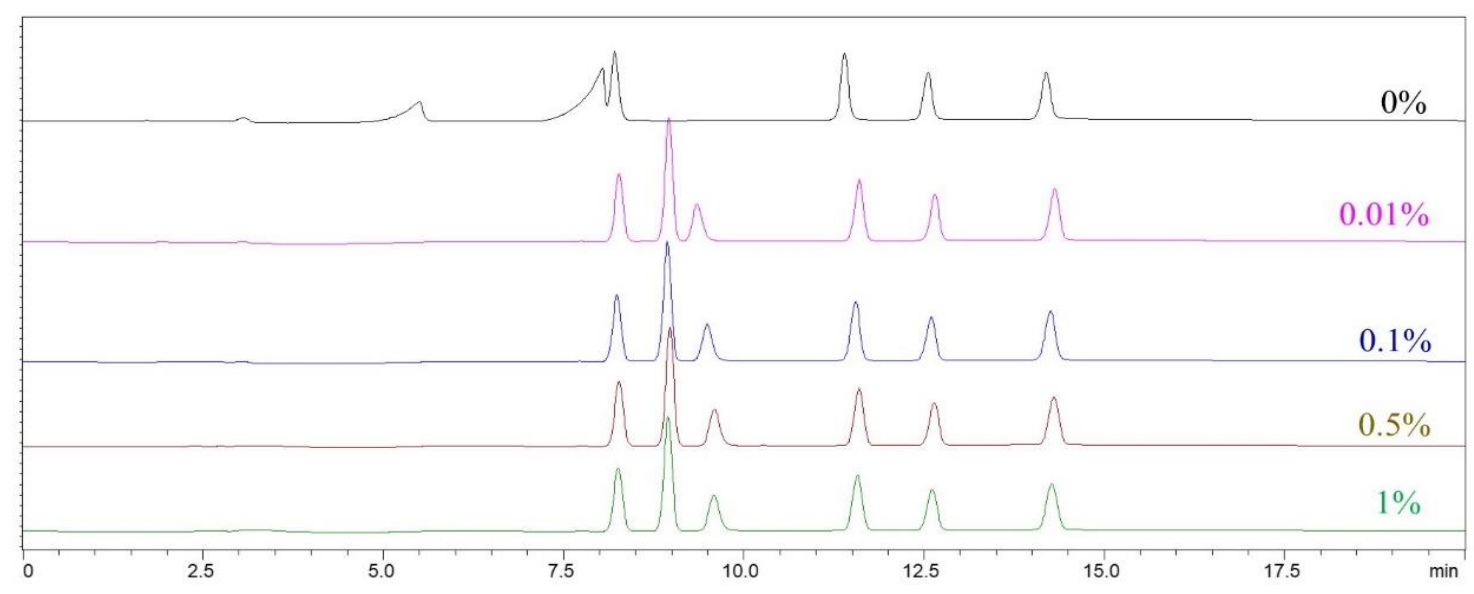

Figure 5. Standard mixture chromatograms of the compounds obtained in the $0.0 \%-0.01 \%-0.1 \%-0.5 \%-1.0 \%$ orthophosphoric acidwater

The data obtained as a result of the optimization of the mobile phase A composition are given in the Table 3. The Rs. value for Rhein-IS in the $0.0 \%$ orthophosphoric acid-water mixture is 0.848 and these two peaks are not separated (Figure 5). However, the data show that the R.s values of the Rhein-IS peak pair increased with increasing orthophosphoric acid-water ratio and reached a maximum value of 2.227 for $0.5 \%$ orthophosphoric acid-water and remained constant at $1 \%$ orthophosphoric acid-water.

Table 3. Comparison of values obtained for mobile phase A composition optimization

\begin{tabular}{|c|c|c|c|c|c|c|c|}
\hline $\begin{array}{l}\text { Mobile } \\
\text { Phase A }\end{array}$ & Compounds & $\mathbf{k}_{\mathbf{2}}$ & $\alpha$ & $\mathbf{k}_{2} /\left(\mathbf{k}_{2}+1\right)$ & $(\alpha-1) / \alpha$ & $(1 / 4) \sqrt{N}$ & $\mathbf{R}_{\mathbf{s}}$ \\
\hline \multirow{5}{*}{$0.0 \%$} & I.S/Aloe-emodin & 1.714 & 2.002 & 0.632 & 0.500 & 10.560 & 3.337 \\
\hline & Rhein/I.S & 1.776 & 1.036 & 0.640 & 0.035 & 37.856 & 0.848 \\
\hline & Emodin/ Rhein & 2.855 & 1.603 & 0.741 & 0.376 & 52.337 & 14.582 \\
\hline & Chrysophanol/Emodin & 3.243 & 1.137 & 0.764 & 0.120 & 53.878 & 4.940 \\
\hline & Physcion/Chrysophanol & 3.802 & 1.171 & 0.792 & 0.146 & 57.527 & 6.652 \\
\hline $0.01 \%$ & I.S/Aloe-emodin & 1.910 & 1.134 & 0.656 & 0.118 & 42.071 & 3.257 \\
\hline
\end{tabular}




\begin{tabular}{|c|c|c|c|c|c|c|c|}
\hline & Rhein/I.S & 2.039 & 1.068 & 0.671 & 0.064 & 35.969 & 1.545 \\
\hline & Emodin/ Rhein & 2.769 & 1.358 & 0.735 & 0.264 & 49.089 & 9.525 \\
\hline & Chrysophanol/Emodin & 3.111 & 1.124 & 0.757 & 0.110 & 52.524 & 4.374 \\
\hline & Physcion/Chrysophanol & 3.652 & 1.174 & 0.785 & 0.148 & 54.959 & 6.385 \\
\hline \multirow{5}{*}{$0.1 \%$} & I.S/Aloe-emodin & 1.929 & 1.135 & 0.659 & 0.119 & 40.547 & 3.180 \\
\hline & Rhein/I.S & 2.112 & 1.095 & 0.679 & 0.087 & 35.051 & 2.071 \\
\hline & Emodin/ Rhein & 2.789 & 1.321 & 0.736 & 0.243 & 46.793 & 8.369 \\
\hline & Chrysophanol/Emodin & 3.132 & 1.123 & 0.758 & 0.110 & 49.586 & 4.134 \\
\hline & Physcion/Chrysophanol & 3.676 & 1.174 & 0.786 & 0.148 & 52.479 & 6.105 \\
\hline \multirow{5}{*}{$0.5 \%$} & I.S/Aloe-emodin & 1.888 & 1.137 & 0.654 & 0.120 & 40.086 & 3.146 \\
\hline & Rhein/I.S & 2.086 & 1.105 & 0.676 & 0.095 & 34.681 & 2.227 \\
\hline & Emodin/ Rhein & 2.734 & 1.311 & 0.732 & 0.237 & 45.557 & 7.903 \\
\hline & Chrysophanol/Emodin & 3.070 & 1.123 & 0.754 & 0.110 & 48.225 & 4.000 \\
\hline & Physcion/Chrysophanol & 3.604 & 1.174 & 0.783 & 0.148 & 50.603 & 5.864 \\
\hline \multirow{5}{*}{$1.0 \%$} & I.S/Aloe-emodin & 1.927 & 1.134 & 0.658 & 0.118 & 38.738 & 3.008 \\
\hline & Rhein/I.S & 2.135 & 1.108 & 0.681 & 0.097 & 33.722 & 2.227 \\
\hline & Emodin/ Rhein & 2.786 & 1.305 & 0.736 & 0.234 & 44.035 & 7.584 \\
\hline & Chrysophanol/Emodin & 3.126 & 1.122 & 0.758 & 0.109 & 46.448 & 3.838 \\
\hline & Physcion/Chrysophanol & 3.669 & 1.174 & 0.786 & 0.148 & 48.941 & 5.593 \\
\hline
\end{tabular}

In earlier studies, separation of the compounds was carried out using $0.01 \%$ phosphoric acid-water (Zou et al., 2008), 0.1\% phosphoric acid-water (Wei et al., 2013) and $0.05 \%$ phosphoric acid-water (Uzun\&Demirezer, 2019) as the mobile phase composition. According to the data obtained in our study, $0.5 \%$ phosphoric acid-water was chosen to use as the mobile phase A composition.

\section{Flow rate}

In HPLC studies, a fast separation of the compounds is preferred so it is undesirable to have the flow rate to be below a certain value. Therefore, five different flow rates $(1.5 \mathrm{~mL} / \mathrm{min}, 1.2$ $\mathrm{mL} / \mathrm{min}, 1.0 \mathrm{~mL} / \mathrm{min}, 0.8 \mathrm{~mL} / \mathrm{min}$ and $0.5 \mathrm{~mL} / \mathrm{min}$ ) tested for the optimum flow rate value. The data obtained data are given in Table 4 and the chromatograms in Figure 6. The Table 4 clearly shows that the lower the flow rate, the slower the compounds leave the column and consequently the retention times in the column increase. Figure 6 shows that the retention times of the compounds increase at a flow rate of $0.5 \mathrm{~mL} / \mathrm{min}$ and the physcion peak does not leave the column during the method period. Therefore, the flow rate of $0.5 \mathrm{~mL} / \mathrm{min}$ was not included in the calculations.

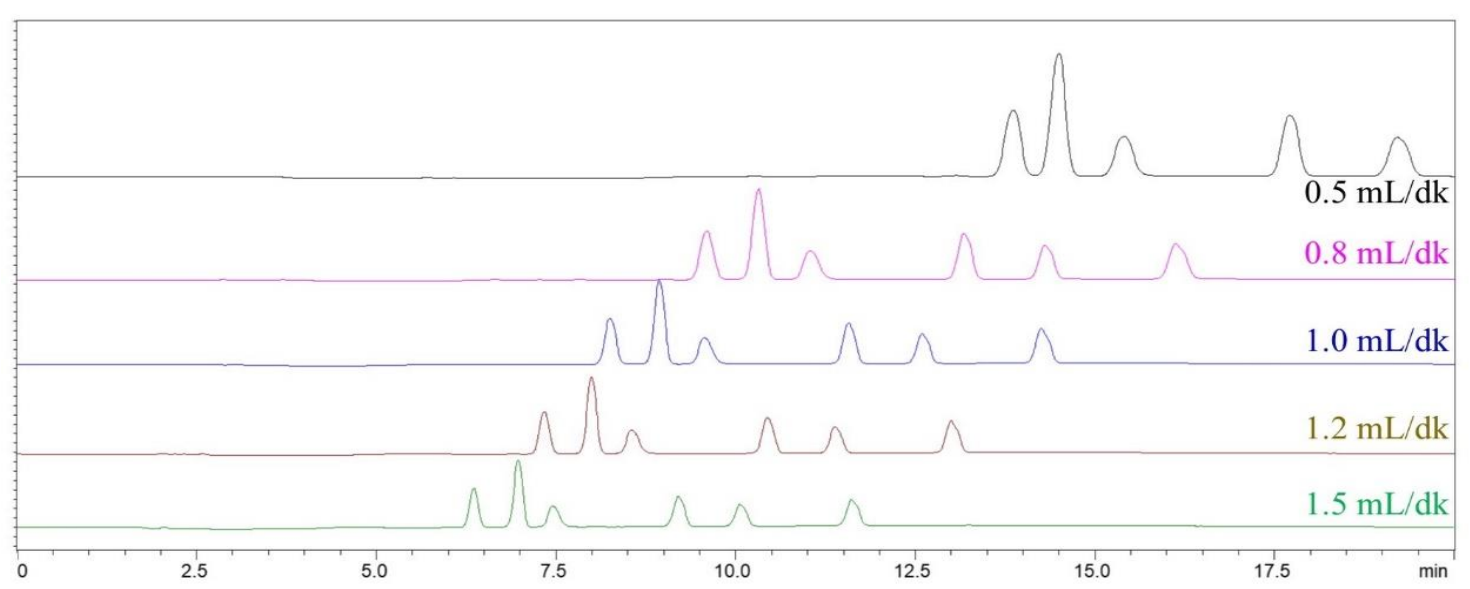

Figure 6. Standard mixture chromatograms of compounds obtained at flow rates of $1.5 \mathrm{~mL} / \mathrm{min}, 1.2 \mathrm{~mL} / \mathrm{min}, 1.0 \mathrm{~mL} / \mathrm{min}, 0.8$ $\mathrm{mL} / \mathrm{min}$ and $0.5 \mathrm{~mL} / \mathrm{min}$

Table 4. Comparison of values obtained for flow rate optimization 
European Journal of Science and Technology

\begin{tabular}{|c|c|c|c|c|c|c|c|}
\hline $\begin{array}{l}\text { Flow rate } \\
(\mathrm{mL} / \mathrm{min})\end{array}$ & Compounds & $\mathbf{k}_{2}$ & $\alpha$ & $\mathbf{k}_{2} /\left(\mathbf{k}_{2}+\mathbf{1}\right)$ & $(\alpha-1) / \alpha$ & $(1 / 4) \sqrt{N}$ & $\mathbf{R}_{\mathbf{s}}$ \\
\hline \multirow{5}{*}{$0.8 \mathrm{~mL} / \mathrm{min}$} & I.S/Aloe-emodin & 1.678 & 1.124 & 0.627 & 0.110 & 32.576 & 2.247 \\
\hline & Rhein/I.S & 1.864 & 1.110 & 0.651 & 0.099 & 28.303 & 1.824 \\
\hline & Emodin/ Rhein & 2.419 & 1.297 & 0.708 & 0.229 & 37.775 & 6.125 \\
\hline & Chrysophanol/Emodin & 2.710 & 1.120 & 0.730 & 0.107 & 39.745 & 3.104 \\
\hline & Physcion/Chrysophanol & 3.183 & 1.175 & 0.761 & 0.149 & 37.524 & 4.255 \\
\hline \multirow{5}{*}{$1.0 \mathrm{~mL} / \mathrm{min}$} & I.S/Aloe-emodin & 1.883 & 1.133 & 0.653 & 0.117 & 32.632 & 2.493 \\
\hline & Rhein/I.S & 2.086 & 1.108 & 0.676 & 0.097 & 29.275 & 1.920 \\
\hline & Emodin/ Rhein & 2.734 & 1.311 & 0.732 & 0.237 & 36.529 & 6.337 \\
\hline & Chrysophanol/Emodin & 3.064 & 1.121 & 0.754 & 0.108 & 38.213 & 3.112 \\
\hline & Physcion/Chrysophanol & 3.599 & 1.175 & 0.783 & 0.149 & 40.324 & 4.704 \\
\hline \multirow{5}{*}{$1.2 \mathrm{~mL} / \mathrm{min}$} & I.S/Aloe-emodin & 2.100 & 1.133 & 0.677 & 0.117 & 31.409 & 2.488 \\
\hline & Rhein/I.S & 2.317 & 1.103 & 0.699 & 0.093 & 26.581 & 1.728 \\
\hline & Emodin/ Rhein & 3.050 & 1.316 & 0.753 & 0.240 & 34.641 & 6.260 \\
\hline & Chrysophanol/Emodin & 3.415 & 1.120 & 0.773 & 0.107 & 36.375 & 3.009 \\
\hline & Physcion/Chrysophanol & 4.042 & 1.184 & 0.802 & 0.155 & 40.384 & 5.020 \\
\hline \multirow{5}{*}{$1.5 \mathrm{~mL} / \mathrm{min}$} & I.S/Aloe-emodin & 2.416 & 1.144 & 0.707 & 0.126 & 29.956 & 2.669 \\
\hline & Rhein/I.S & 2.652 & 1.098 & 0.726 & 0.089 & 25.583 & 1.653 \\
\hline & Emodin/ Rhein & 3.510 & 1.324 & 0.778 & 0.245 & 32.153 & 6.129 \\
\hline & Chrysophanol/Emodin & 3.930 & 1.120 & 0.797 & 0.107 & 33.930 & 2.894 \\
\hline & Physcion/Chrysophanol & 4.695 & 1.195 & 0.824 & 0.163 & 37.541 & 5.042 \\
\hline
\end{tabular}

The Rs values of the Rhein-I.S peak pair were calculated as 1.824 and 1.920 at flow rates of $0.8 \mathrm{~mL} / \mathrm{min}$ and $1.0 \mathrm{~mL} / \mathrm{min}$, respectively; it gradually decreased after flow rate of $1.0 \mathrm{~mL} / \mathrm{min}$. According to these results, the optimum flow rate in the study was determined as $1.0 \mathrm{~mL} / \mathrm{min}$.

In the literature, it had been reported that $1.0 \mathrm{~mL} / \mathrm{min}$ flow rate was generally used in the analysis of aloe-emodin, rhein, emodin, chrysophanol and physcion by HPLC with different mobile phases (Uzun\&Demirezer, 2019; Gautam et al., 2011; VanMen et al., 2012; Zou et al., 2008; He et al., 2009). Shi et al. (Shi et al., 2014) used as $0.8 \mathrm{~mL} / \mathrm{min}$ and Wang et al. (Wang et al., 2013) used $0.5 \mathrm{~mL} / \mathrm{min}$ flow rate in their studies. Thus, the flow rate of
$1.0 \mathrm{~mL} / \mathrm{min}$ determined in this study is compatible with the general results obtained in the literature.

\section{Column temperature}

In order to determine the optimum column temperature, five different column temperatures were studied $\left(20{ }^{\circ} \mathrm{C}, 25^{\circ} \mathrm{C}, 30{ }^{\circ} \mathrm{C}\right.$, $35{ }^{\circ} \mathrm{C}$ and $40{ }^{\circ} \mathrm{C}$ ) and resulting chromatograms are given in the Figure 7. It is seen from the chromatograms that the retention times of the compounds decrease with the increasing temperature, but the peaks become closer to each other. In chromatographic studies, it is desired a short retention time and also high resolution for the studied substances.

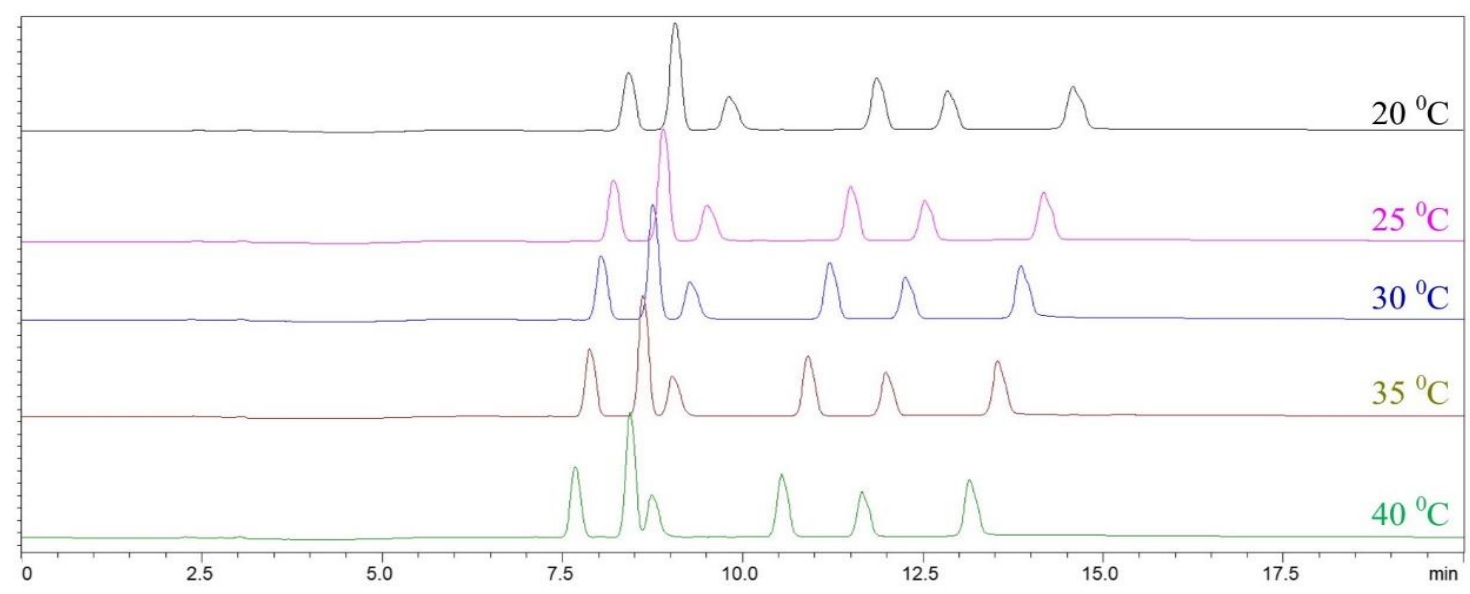


Figure 7. Standard mixture chromatograms of the compounds obtained at column temperatures of $20{ }^{\circ} \mathrm{C}, 25^{\circ} \mathrm{C}, 30{ }^{\circ} \mathrm{C}, 35^{\circ} \mathrm{C}$ and $40{ }^{\circ} \mathrm{C}$

The data obtained in the column temperature optimization study are given in Table 5. It was found that as the column temperature increased, the resolution value of the Rhein-I.S peak pair decreased and this value was less than 1.5 after $30^{\circ} \mathrm{C}$. The Figure
7 shows that as the temperature increases, the peaks get close to each other, and the Rhein-I.S peaks do not separate at $35{ }^{\circ} \mathrm{C}$ and $40{ }^{\circ} \mathrm{C}$. Therefore, $20{ }^{\circ} \mathrm{C}$ column temperature was chosen since the resolution of Rhein and I.S peaks was the highest.

Table 5. Comparison of values obtained for column temperature optimization

\begin{tabular}{|c|c|c|c|c|c|c|c|}
\hline $\begin{array}{c}\text { Column } \\
\text { Temperature }\end{array}$ & Compounds & $\mathbf{k}_{2}$ & $\boldsymbol{\alpha}$ & $\mathbf{k}_{2} /\left(\mathbf{k}_{2}+1\right)$ & $(\alpha-1) / \alpha$ & $(1 / 4) \sqrt{N}$ & $\mathbf{R}_{\mathbf{s}}$ \\
\hline \multirow{5}{*}{$20^{\circ} \mathrm{C}$} & I.S/Aloe-emodin & 1.685 & 1.129 & 0.628 & 0.114 & 31.428 & 2.250 \\
\hline & Rhein/I.S & 1.906 & 1.131 & 0.656 & 0.116 & 26.682 & 2.030 \\
\hline & Emodin/ Rhein & 2.514 & 1.319 & 0.715 & 0.242 & 35.135 & 6.079 \\
\hline & Chrysophanol/Emodin & 2.806 & 1.116 & 0.737 & 0.104 & 36.819 & 2.822 \\
\hline & Physcion/Chrysophanol & 3.212 & 1.145 & 0.763 & 0.127 & 37.114 & 3.596 \\
\hline \multirow{5}{*}{$25^{\circ} \mathrm{C}$} & I.S/Aloe-emodin & 1.879 & 1.135 & 0.653 & 0.119 & 32.092 & 2.494 \\
\hline & Rhein/I.S & 2.074 & 1.104 & 0.675 & 0.094 & 27.217 & 1.727 \\
\hline & Emodin/ Rhein & 2.719 & 1.311 & 0.731 & 0.237 & 35.491 & 6.149 \\
\hline & Chrysophanol/Emodin & 3.051 & 1.122 & 0.753 & 0.109 & 37.072 & 3.043 \\
\hline & Physcion/Chrysophanol & 3.584 & 1.175 & 0.782 & 0.149 & 39.347 & 4.585 \\
\hline \multirow{5}{*}{$30^{\circ} \mathrm{C}$} & I.S/Aloe-emodin & 1.834 & 1.145 & 0.647 & 0.127 & 31.999 & 2.629 \\
\hline & Rhein/I.S & 2.000 & 1.091 & 0.667 & 0.083 & 27.692 & 1.533 \\
\hline & Emodin/ Rhein & 2.626 & 1.313 & 0.724 & 0.277 & 35.218 & 7.063 \\
\hline & Chrysophanol/Emodin & 2.967 & 1.130 & 0.748 & 0.115 & 36.791 & 3.165 \\
\hline & Physcion/Chrysophanol & 3.484 & 1.174 & 0.777 & 0.148 & 38.715 & 4.452 \\
\hline \multirow{5}{*}{$35^{\circ} \mathrm{C}$} & I.S/Aloe-emodin & 1.786 & 1.155 & 0.641 & 0.134 & 32.221 & 2.768 \\
\hline & Rhein/I.S & 1.918 & 1.073 & 0.657 & 0.068 & 28.147 & 1.257 \\
\hline & Emodin/ Rhein & 2.526 & 1.316 & 0.716 & 0.240 & 35.368 & 6.078 \\
\hline & Chrysophanol/Emodin & 2.877 & 1.138 & 0.742 & 0.121 & 34.852 & 3.129 \\
\hline & Physcion/Chrysophanol & 3.379 & 1.174 & 0.772 & 0.148 & 40.117 & 4.584 \\
\hline \multirow{5}{*}{$40^{\circ} \mathrm{C}$} & I.S/Aloe-emodin & 1.791 & 1.162 & 0.642 & 0.139 & 32.445 & 2.895 \\
\hline & Rhein/I.S & 1.892 & 1.056 & 0.654 & 0.053 & 28.350 & 0.983 \\
\hline & Emodin/ Rhein & 2.488 & 1.315 & 0.713 & 0.240 & 35.516 & 6.077 \\
\hline & Chrysophanol/Emodin & 2.857 & 1.148 & 0.741 & 0.129 & 35.152 & 3.360 \\
\hline & Physcion/Chrysophanol & 3.350 & 1.172 & 0.770 & 0.147 & 37.565 & 4.252 \\
\hline
\end{tabular}

As a result of the literature review, it is seen that the column temperature of $25{ }^{\circ} \mathrm{C}$ was usually determined in HPLC methods (Zou et al., 2008; Wei et al., 2013; He et al., 2009; Ahmad et al., 2014). In the studies conducted by Feng et al., (Feng et al., 2017) and Sharma et al.(Sharma et al., 2012), $30{ }^{\circ} \mathrm{C}$ was used as the column temperature. Wang et al. (Wang et al., 2013) determined the column temperature as $35^{\circ} \mathrm{C}$; Gao et al. (Gao et al., 2009) and Shi et al. (Shi et al., 2014) determined it as $40{ }^{\circ} \mathrm{C}$.

\section{Optimum conditions}

For the method to be used in the separation of compounds, three different columns, two different mobile phases B, five different mobile phase A compositions, five different flow rates and five different column temperatures were evaluated and the optimum separation conditions were determined (Table 6).

Table 6. The Optimum Chromatographic Conditions

\begin{tabular}{|c|c|}
\hline \multicolumn{1}{|c|}{ Column } & Supelcosil LC-18 $(250 \mathrm{~mm} \times 4,6 \mathrm{~mm}$, \\
\hline Wavelength & $225 \mathrm{~nm}$ \\
\hline Injection volume & $20 \mu \mathrm{L}$ \\
\hline Mobile Phase A & $\mathrm{dH}_{2} \mathrm{O}+0.5 \%$ orthophosphoric acid \\
\hline Mobile Phase B & Methanol \\
\hline
\end{tabular}




\begin{tabular}{|l|c|}
\hline \multicolumn{1}{|c|}{ Flow rate } & $1.0 \mathrm{~mL} / \mathrm{min}$ \\
\hline Column & $20^{\circ} \mathrm{C}$ \\
\hline Injection time & $20 \mathrm{~min}$ \\
\hline
\end{tabular}

for aloe-emodin, rhein, emodin, chrysophanol and physcion, respectively. This study on the simultaneous separation and determination of the anthraquinones was compared with the results from previous studies. In the studies of Chen et al., 2020, Rong et al., 2011 and Zhan et al., 2017; they separated these five anthraquinones in 22.5, 24.44 and 40,0 minutes, respectively. In

\section{Separation of compounds at optimum conditions}

The standard mixture chromatogram obtained under the optimized condition is given in the Figure 8. The retention times were found to be $8.413,9.806,11.858,12.840$ and 14.579 minutes this study separated five anthraquinones only 15 minutes. It observed that the developed method is sensitive, effective and selective and the retention time is shorter (Wang et al., 2016; Wei et al., 2013; Chen et al., 2020; Rong et al., 2011; Zhan et al., 2017).

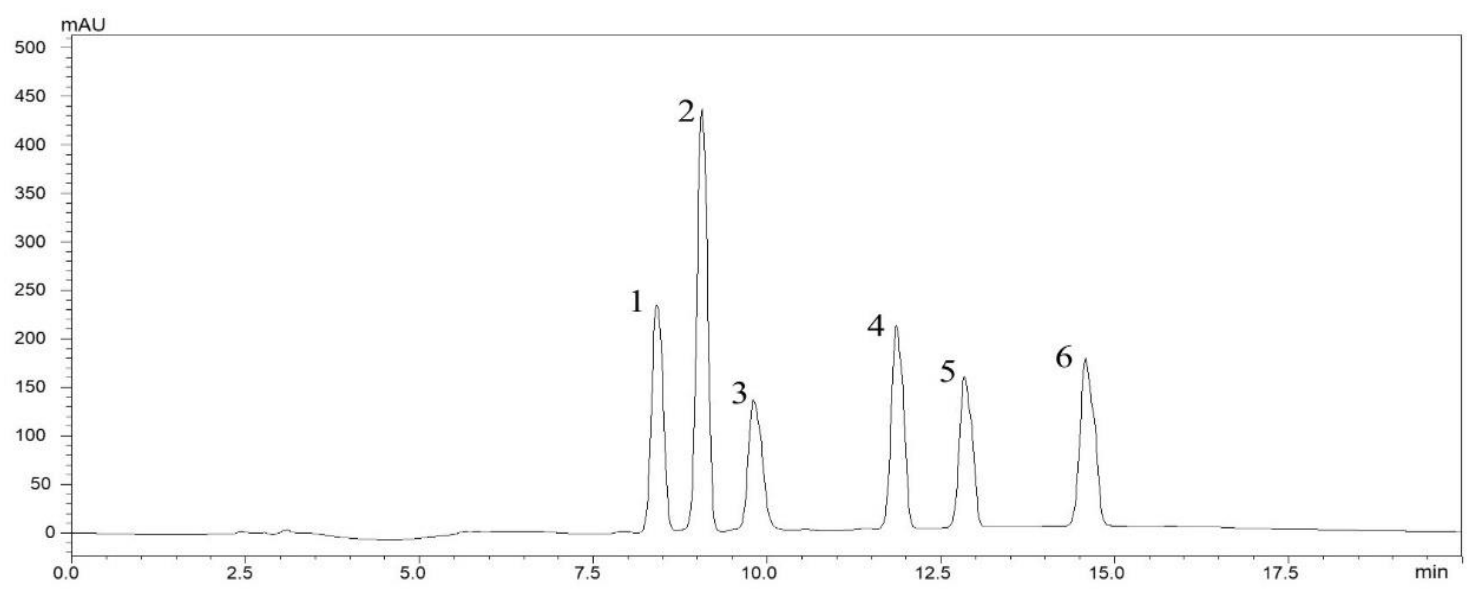

Figure 8. Chromatogram of standard mixture (1-Aloe-emodin, 2-I.S, 3-Rhein, 4-Emodin, 5-Chrysophanol, 6-Physicon)

The chromatographic data obtained under optimum conditions are good baseline resolution was obtained for the aloe-emodin, the rhein, the emodin, the chrysophanol and the physcion.

shown in Table 7. Under the proposed optimization conditions,

Table 7. The capacity factors, selectivity, and resolution factor values for the compounds studied

\begin{tabular}{|c|c|c|c|c|c|c|}
\hline Compounds & $\mathbf{k}_{\mathbf{2}}$ & $\boldsymbol{\alpha}$ & $\mathbf{k}_{\mathbf{2}} /\left(\mathbf{k}_{\mathbf{2}}+\mathbf{1}\right)$ & $\mathbf{( \alpha - 1 ) / \boldsymbol { \alpha }}$ & $\mathbf{( 1 / 4 )} \sqrt{\mathbf{N}}$ & $\mathbf{R}_{\mathbf{s}}$ \\
\hline I.S/Aloe-emodin & 1.685 & 1.129 & 0.628 & 0.114 & 31.428 & 2.250 \\
\hline Rhein/I.S & 1.906 & 1.131 & 0.656 & 0.116 & 26.682 & 2.030 \\
\hline Emodin/ Rhein & 2.514 & 1.319 & 0.715 & 0.242 & 35.135 & 6.079 \\
\hline Chrysophanol/Emodin & 2.806 & 1.116 & 0.737 & 0.104 & 36.819 & 2.822 \\
\hline Physcion/Chrysophanol & 3.212 & 1.145 & 0.763 & 0.127 & 37.114 & 3.596 \\
\hline
\end{tabular}

\section{Conclusions and Recommendations}

In this study, an RP-HPLC method was successfully developed for the simultaneous separation of the five anthraquinones compounds (aloe-emodin, rhein, emodin, chrysophanol and physcion). The developed method was optimized properly utilizing a Supercosil LC- 18 column at the $20{ }^{\circ} \mathrm{C}$ with a $0.5 \%$ orthophosphoric acid-water mixture as the mobile phase $\mathrm{A}$ and methanol as the mobile phase B. The injection volume of $20 \mu \mathrm{L}$ and the flow rate of $1.0 \mathrm{~mL} / \mathrm{min}$ were studied with a DAD detector at $225 \mathrm{~nm}$. In determination of the optimum separation conditions the capacity factor, the selectivity and the resolution parameters were all found to be above the reference values and five different standards were separated efficiently in 15 minutes. Therefore, this efficient RP-HPLC method can be recommended as the preferred separation method for the anthraquinones as both determination and routine analysis.

\section{References}

Agarwal, S.K., Singh, S.S., Verma, S., \& Kumar, S., (2000). Antifungal activity of anthraquinone derivatives from Rheum emodi. Journal of Ethnopharmacology, 72 (1-2), 43-46. doi: 10.1016/s0378-8741(00)00195-1

Ahmad, W., Zaidi, S.M.A., Mujeeb, M., Ansari, S.H., \& Ahmad, S., (2014). HPLC and HPTLC Methods by Design for Quantitative Characterization and in vitro Anti-oxidant 
Activity of Polyherbal Formulation Containing Rheum emodi. Journal of Chromatographic Science, 52 (8), 911-918. doi: 10.1093/chromsci/bmt123

Aichner, D., \& Ganzera, M., (2015). Analysis of anthraquinones in rhubarb (Rheum palmatum and Rheum officinale) by supercritical fluid chromatography. Talanta, 144, 1239-1244. doi: 10.1016/j.talanta.2015.08.011

Chen, C., Fu, Z., Zhou, W., Chen, Q., Wang, C., Xu, L., Wang, Z. and Zhang, H., (2020). Ionic liquid-immobilized NaY zeolitebased matrix solid phase dispersion for the extraction of active constituents in Rheum palmatum L. Microchemical Journal, 152, 104245. doi: 10.1016/j.microc.2019.104245

Chen, S.H., Lin, K.Y., Chang, C.C., Fang, C.L., \& Lin, C.P., (2007). Aloe-emodin-induced apoptosis in human gastric carcinoma cells. Food and Chemical Toxicology, 45 (11), 2296-2303. doi: 10.1016/j.fct.2007.06.005

Chien, S.C., Wu, Y.C., Chen, Z.W., \& Yang, W.C., (2015). Naturally occurring anthraquinones: chemistry and therapeutic potential in autoimmune diabetes. EvidenceBased Complementary and Alternative Medicine, Article ID 357357. doi: 10.1155/2015/357357

ElSohly, M.A., Gul, W., \& Murphy, T.P., (2004). Analysis of the anthraquinones aloe-emodin and aloin by gas chromatography/mass spectrometry. International Immunopharmacology, 4 (14), 1739-1744. doi: 10.1016/j.intimp.2004.07.005

Farooq, U., Pandith, S.A., Singh, Saggoo, M.I., \& Lattoo, S.K., (2013). Altitudinal variability in anthraquinone constituents from novel cytotypes of Rumex nepalensis Spreng-a high value medicinal herb of North Western Himalayas. Industrial Crops and Products, 50, 112-117. doi: 10.1016/j.indcrop.2013.06.044

Feng, S.X., Li, M.M., Zhao, D., Li, X.H., Zhang, L., Wang, Z., \& Gao, N.N., (2017). Simultaneous Determination of 10 Anthraquinones in Rhubarb Based on HPLC-Q-HR/MS. Chinese Herbal Medicines, 9 (4), 388-395. doi: 10.1016/S1674-6384(17)60120-5

Gao, X.Y., Jiang, Y., Lu, J., \& Tu, P-.F., (2009). One single standard substance for the determination of multiple anthraquinone derivatives in rhubarb using high-performance liquid chromatography-diode array detection. Journal of Chromatography A, 1216 (11), 2118-2123. doi: 10.1016/j.chroma.2008.11.104

Gautam, R., Srivastava, A., \& Jachak, S.M., (2011). Simultaneous Determination of Naphthalene and Anthraquinone Derivatives in Rumex nepalensis Spreng. Roots by HPLC: Comparison of Different Extraction Methods and Validation. Phytochemical Analysis, 22 (2), 153-157. doi: 10.1002/pca.1261

Guo, S., Feng, B., Zhu, R., Ma, J., \& Wang, W., (2011). Preparative Isolation of Three Anthraquinones from Rumex japonicus by High-Speed Counter-Current Chromatography. Molecules, $16 \quad$ (2), 1201-1210. doi: 10.3390/molecules 16021201

He, D., Chen, B., Tian, Q., \& Yao, S., (2009). Simultaneous determination of five anthraquinones in medicinal plants and pharmaceutical preparations by HPLC with fluorescence detection. Journal of Pharmaceutical and Biomedical Analysis, 49 (4), 1123-1127. doi: 10.1016/j.jpba.2009.02.014

Hu, S.S., Cao, W., Dai, H.B., Da, J.H., Ye, L.H., Cao, J., \& Li, X.Y., (2014). Ionic-liquid-micelle-functionalized mesoporous $\mathrm{Fe} 3 \mathrm{O} 4$ microspheres for ultraperformance liquid chromatography determination of anthraquinones in dietary supplements. Journal of Agricultural and Food Chemistry, 62 (35), 8822-8829. doi: 10.1021/jf502323f

Iizuka, A., Iijima, O.T., Kondo, K., Itakura, H., Yoshie, F., Miyamoto, H., Kubo, M., Higuchi, M., Takeda, H., \& Matsumiya, R., (2004). Evaluation of Rhubarb using antioxidative activity as an index of pharmacological usefulness. Journal of Ethnopharmacology, 91 (1), 89-94. doi: 10.1016/j.jep.2003.11.021

Koyama, J., Morita, I., \& Kobayashi, N., (2007). Simultaneous determination of anthraquinones in rhubarb by highperformance liquid chromatography and capillary electrophoresis. Journal of Chromatography A, 1145 (1-2), 183-189. doi: 10.1016/j.chroma.2007.01.076

Koyama, J., Morita, I., Tagahara, K., Nobukuni, Y., Mukainaka, T., Kuchide, M., Tokuda, H., \& Nishino, H., (2002). Chemopreventive effects of emodin and cassiamin B in mouse skin carcinogenesis. Cancer Letters, 182 (2), 135-139. doi: 10.1016/S0304-3835(02)00100-3

Kuo, C.H., \& Sun, S.W., (2003). Analysis of nine rhubarb anthraquinones and bianthrones by micellar electrokinetic chromatography using experimental design. Analytica Chimica Acta, 482 (1), 47-58. doi: 10.1016/S00032670(03)00169-7

Liu, S.Y., Sporer, F., Wink, M., Jourdane, J., Henning, R., Li, Y.L., \& Ruppel, A., (1997). Anthraquinones in Rheum palmatum and Rumex dentatus (Polygonaceae), and phorbol esters in Jatropha curcas (Euphorbiaceae) with molluscicidal activity against the schistosome vector snails Oncomelania, Biomphalaria, and Bulinus. Tropical Medicine and International Health, 2 (2): 179-188. doi: 10.1046/j.13653156.1997.d01-242.x

Li-Weber M., (2013). Targeting apoptosis pathways in cancer by Chinese medicine. Cancer Letters, 332 (2), 304-312. doi: 10.1016/j.canlet.2010.07.015

Locatelli M., (2011). Anthraquinones: analytical techniques as a novel tool to investigate on the triggering of biological targets. Current Drug Targets, 12 (3) 366-380. doi: 10.2174/138945011794815338

Lü, H., Wang, J., Wang, X., Lin, X., Wu, X., \& Xie Z., (2007). Rapid separation and determination of structurally related anthraquinones in Rhubarb by pressurized capillary electrochromatography. Journal of Pharmaceutical and Biomedical Analysis, 43 (1), 352-357. doi: 10.1016/j.jpba.2006.06.023

Mandrioli, R., Mercolini, L., Ferranti, A., Fanali, S., \& Raggi, M.A., (2011). Determination of aloe emodin in Aloe vera extracts and commercial formulations by HPLC with tandem UV absorption and fluorescence detection. Food Chemistry, 126 (1), 387-393. doi: 10.1016/j.foodchem.2010.10.112

Mehta, J., (2012). Separation and characterization of anthraquinone derivatives from Cassia fistula using chromatographic and spectral techniques. International Journal of Chemical Sciences, 10(1), 306-316.

Rafaelly, L., Heron, S., Nowik, W., \& Tchapla, A., (2008). Optimisation of ESI-MS detection for the HPLC of anthraquinone dyes. Dyes and Pigments, 77 (1), 191-203. doi: 10.1016/j.dyepig.2007.05.007

Reynolds T., (2004). Aloes: The genus Aloe (Medicinal and Aromatic Plants - Industrial Profiles). CRC Press.

Rong, F., Xi, H., Yang, W., Ping, R., Feng, Q., Chunhu, Z., Lan, F., Lichen, G., Zhaoqian, L., \& Honghao, Z., (2011). Determination of anthraquinones by UPLC method in patient 
with craniocerebral injuries after oral administration of rhubarb. Word Science and Technology, 13, 676-680.

Shang, X., \& Yuan, Z., (2003). Determination of hydroxyanthraquinoids in Rhubarb by cyclodextrin-modified micellar electrokinetic chromatography using a mixed micellar system of sodium dodecyl sulfate and sodium cholate. Journal of Pharmaceutical and Biomedical Analysis, 31 (1), 75-81. doi: 10.1016/s0731-7085(02)00596-4

Sharma, N., Kumar, R., Sinha, A.K., Reddy, P.B., Nayeem, S.M., \& Deep, S., (2012). Anthraquinone derivatives based natural dye from Rheum emodi as a probe for thermal stability of proteins: Spectroscopic and chromatographic studies. Journal of Pharmaceutical and Biomedical Analysis, 62, 96104. doi: 10.1016/j.jpba.2011.12.017

Shi, Y.B., Li, H.L., Wang, H.Q., Yang, Y.B., Zhang, X.Y., Wang, H., Zhu, Z.J., Zhang, Z.Y., \& Zhang, C.A., (2014). Simultaneous determination of five anthraquinones in a Chinese traditional preparation by RP-HPLC using an improved extraction procedure. Journal of Integrative Medicine 12 (5), 455-462. doi: 10.1016/S20954964(14)60037-6

Singh, N.P., Gupta, A.P., Sinha, A.K., \& Ahuja, P.S., (2005). Highperformance thin layer chromatography method for quantitative determination of four major anthraquinone derivatives in Rheum emodi. Journal of Chromatography A, 1077 (2), 202-206. doi: 10.1016/j.chroma.2005.03.130

Smolarz, H.D., Swatko-Ossor, M., Ginalska, G., \& Medynska, E., (2013). Antimycobacterial effect of extract and its components from Rheum rhaponticum. Journal of $A O A C$ International, 96 (1), 155-160. doi: 10.5740/jaoacint.12-010

Su, Y.T., Chang, H.L., Shyue, S.K., \& Hsu, S.L., ( 2005). Emodin induces apoptosis in human lung adenocarcinoma cells through a reactive oxygen species-dependent mitochondrial signaling pathway. Biochemical Pharmacology, 70 (2), 229241. doi: 10.1016/j.bcp.2005.04.026

Sun, S.W., \& Yeh, P.C., (2005). Analysis of rhubarb anthraquinones and bianthrones by microemulsion electrokinetic chromatography. Journal of Pharmaceutical and Biomedical Analysis 36, (5), 995-1001. doi: 10.1016/j.jpba.2004.08.039

Tian, J., Chen, X. and Bai, X., (2012). Comparison of dispersive liquid-liquid microextraction based on organic solvent and ionic liquid combined with high-performance liquid chromatography for the analysis of emodin and its metabolites in urine samples. Journal of Separation Science, 35 (1), 145-152. doi: 10.1002/jssc.201100729

Tian, K., Wang, Y., Chen, Y., Chen, X., \& Hu, Z., (2007). Application of 1-alkyl-3-methylimidazolium-based ionic liquids as background electrolyte in capillary zone electrophoresis for the simultaneous determination of five anthraquinones in Rhubarb. Talanta, 72 (2), 587-593. doi: 10.1016/j.talanta.2006.11.027

Uzun, M., \& Demirezer, L.O., (2019). Anti-aging power of Rumex crispus L.: Matrixmetalloproteinases inhibitor, sun protective and antioxidant. South African Journal of Botany, 124, 364371. doi: 10.1016/j.sajb.2019.05.028

VanMen, C., Jang, Y.S., Zhu, H.M., Lee, J.H., Trung, T.N., Ngoc, T.M., Kim, Y.K., \& Kang, J.K., (2012). Chemical-based species classification of rhubarb using simultaneous determination of five bioactive substances by HPLC and LDA analysis. Phytochemical Analysis, 23 (4), 359-364. doi: $10.1002 /$ pca. 1365
Wang, A., Zhou, Y., Wu, F., He, P., \& Fang, Y., (2004). Determination of active ingredients in Huangdan Yinchen Keliby CZE with amperometric detection. Journal of Pharmaceutical and Biomedical Analysis, 35, 959-964. doi:10.1016/j.jpba.2004.02.031

Wang, G.Y., \& Shi, Y.P., (2014). Simultaneous Determination of Anthraquinone Derivatives in Radix et Rhizoma Rhei-based Medicines by Ultra-Performance LC-ESCI-MS/MS Multiple Reaction Monitoring. Acta Chromatographica, 26 (2), 229242. doi: 10.1556/AChrom.26.2014.2.3

Wang, Y., Xiong, H., Zhang, X., \& Wang, S., (2010). Electrochemical study of Aloe-emodin on an ionic liquid-type carbon paste electrode. Microchimica Acta, 169, 255-260. doi: 10.1007/s00604-010-0348-7

Wang, Z., Hu, J., Du, H., He, S., Li, Q., \& Zhang, H., (2016). Microwave-assisted ionic liquid homogeneous liquid-liquid microextraction coupled with high performance liquid chromatography for the determination of anthraquinones in Rheum palmatum L. Journal of Pharmaceutical and Biomedical Analysis, 125, 178-185. doi: 10.1016/j.jpba.2016.03.046

Wang, Z., Ma, P., Xu, L., He, C., \& Peng, Y., (2013). Evaluation of the content variation of anthraquinone glycosides in rhubarb by UPLC-PDA. Chemistry Central Journal, 7 (1), 170. doi: 10.1186/1752-153X-7-170

Wei, S.Y., Yao, W.X., Ji, W.Y., Wei, J.Q., \& Peng, S.Q., (2013). Qualitative and quantitative analysis of anthraquinones in rhubarbs by high performance liquid chromatography with diode array detector and mass spectrometry. Food Chemistry, 141 (3), 1710-1715. doi: 10.1016/j.foodchem.2013.04.074

Wijesekara, I, Zhang, C., Van-Ta, Q., Vo, T.S., Li, Y.X., \& Kim, S.K., (2014). Physcion from marine-derived fungus Microsporum sp. induces apoptosis in human cervical carcinoma HeLa cells. Microbiological Research, 169 (4), 255-261. doi: 10.1016/j.micres.2013.09.001

Wolfender, J.L., Marti, G., Thomas, A., \& Bertrand, S., (2015.) Current approaches and challenges for the metabolite profiling of complex natural extracts. Journal of Chromatography A, 1382, 136-164. doi: 10.1016/j.chroma.2014.10.091

Xu, F., Liu, Y., Zhang, Z., Song, R., Dong, H., \& Tian, Y., (2008). Rapid simultaneous quantification of five active constituents in rat plasma by high-performance liquid chromatography/tandem mass spectrometry after oral administration of Da-Cheng-Qi decoction. Journal of Pharmaceutical and Biomedical Analysis, 47 (3), 586-595. doi: 10.1016/j.jpba.2008.02.005

Yanwen, W., Wenyuan, G., Xiaohe, X., \& Yi, L., (2005). Calorimetric investigation of the effect of hydroxyanthraquinones in Rheum officinale Baill on Staphylococcus aureus growth. Thermochimica Acta, 429, 167-170. doi:10.1016/j.tca.2005.03.008

Yao, X.S., Wu, L.J., \& Wu, J.Z., (2004). Natural Medicine Chemistry. People Health Press;Beijing, China; pp. 150.

Yen, G.C., Duh, P.D., \& Chuang, D.Y., (2000). Antioxidant activity of anthraquinones and anthrone. Food Chemistry, 70 (4), 437-441. doi: 10.1016/s0308-8146(00)00108-4

You, X, Feng, S., Luo, S., Cong, D., Yu, Z., Yang, Z., \& Zhang, J., (2013). Studies on a rhein-producing endophytic fungus isolated from Rheum palmatum L. Fitoterapia, 85 (1), 161168. doi: 10.1016/j.fitote.2012.12.010

Zhan, H., Fang, J., Wu, H.W., Yang, H.J., Li, H., Wang, Z.J., Yang, B., Tang, L.Y., Fu, M.H. Rapid determination of total content 
of five major anthraquinones in Rhei Radix et Rhizoma by NIR spectroscopy. Chinese Herbal Medicines, 2017, vol. 9, no.3, p. 250, 10.1016/S1674-6384(17)60101-1.

Zhang, H.F., \& Shi, Y.P., (2010). Temperature-assisted ionic liquid dispersive liquid-liquid microextraction combined with high performance liquid chromatography for the determination of anthraquinones in Radix et Rhizoma Rhei samples. Talanta, 82 (3), 1010-1016. doi: 10.1016/j.talanta.2010.06.008

Zhang, L.S., Hu, S., Chen, X., Bai, X.H., \& Li, Q.S., (2013). A new ionic liquid-water-organic solvent three phase microextraction for simultaneous preconcentration flavonoids and anthraquinones from traditional Chinese prescription. Journal of Pharmaceutical and Biomedical Analysis, 86, 36-39. doi: 10.1016/j.jpba.2013.07.007

Zou, J.L., Xie, Z.Y., Jiang, X.F., Chen, X.X., \& Yao, M.C., (2008). Determination of Anthraquinones in Different Compatibility of Dahuang Huanglian Xiexin Decoction by HPLC. World Science and Technology, 10 (4), 61-64. doi: 10.1016/S18763553(09)60021-1

Zuo, Y., Wang, C., Lin, Y., Guo, J., \& Deng, Y., (2008). Simultaneous determination of anthraquinones in radix Polygoni multiflori by capillary gas chromatography coupled with flame ionization and mass spectrometric detection. Journal of Chromatography A, 1200 (1), 43-48. doi: 10.1016/j.chroma.2008.01.058 